\title{
Reworking the appraisal framework in ESL research: refining attitude resources
}

Thu $\mathrm{Ngo}^{1 *}$ and Len Unsworth ${ }^{2}$

\author{
* Correspondence: \\ tngo8@une.edu.au \\ ${ }^{1}$ School of Education, University of \\ New England, Armidale 2351, NSW, \\ Australia \\ Full list of author information is \\ available at the end of the article
}

\begin{abstract}
The Appraisal framework within Systemic Functional Linguistics as a robust tool in language teaching and research has attracted a great deal of interest in recent years. Since its establishment as the most complete account, the framework has been used in a variety of contexts, resulting in a number of refinements, tuning its applicability for specific research purposes such as studies of the evaluative language in research article abstracts, biology experiment reports, wine appreciation and student narrative writing. This article proposes additional refinements, particularly to the system of Attitude, informed by research into the deployment of evaluative resources in spoken discourse by postgraduate students in small group discussions in English and in Vietnamese. The refinements were required to account for the range of evaluative language used in discussions of topics including personal experiences of living and studying in Australia, academic experiences at Australian universities, and opinion about one's professional standing. These refinements contribute to the ongoing development of the Appraisal framework and provide a resource for enhancing the effectiveness of expressions of evaluative stance for speakers of English as a second or additional language.
\end{abstract}

Keywords: Appraisal; Evaluative language; Re-theorisation; Refinements; Attitude; Spoken discourse; ESL; International students

\section{Background}

The evaluative functions of language in language teaching and research

The capacity to express one's personal feelings and opinions with precision and sophistication in appropriate contexts has been one of the very important issues in language teaching and research. Through expressing one's feelings and opinions, one can build a particular kind of relationship with the reader/hearer by confirming solidarity with their views or by leading or persuading them towards a certain viewpoint and by finetuning the level of certainty in statements. Particularly, for international students in an English speaking country for whom English is an additional language, the ability to express their personal feelings and opinions in English is essential not only in dealing with academic tasks that require them to express their critical and analytical thinking (Brick 2009) but also in their everyday lives when the capacity to precisely express their feelings and opinions affects their psychological adjustment and levels of acculturative stress (Redmond 2000, Yeh and Inose 2003). To prepare international students whose language background is not English to be able to participate effectively in the everyday, academic 
and professional settings in an English speaking country, it is very important that language teachers are equipped with linguistic understanding of evaluative language so that they can use these resources to enhance their language programs and teaching.

For many language educators and researchers, the evaluative aspect of language has been most popularly established in the theory of Communicative Competence (Savignon 1983, Canale and Swain 1980, Celce-Murcia, Dörnyei, and Thurrell 1995), the basis for the Communicative Language Teaching approach, which has been one of the most common approaches in many parts of the world. Within the theory of Communicative Competence, the evaluative aspect was listed under Interactional Competence, with reference to 'the knowledge of how to perform common speech acts and speech act sets ... involving interactions such as information exchange, interpersonal exchanges, expression of opinions, feelings, problems and future scenarios', etc. (Celce-Murcia 2007, 48). The evaluative functions of language are also reflected in studies from a range of linguistic approaches such as Relational Pragmatics (Kopytko 2000), General Pragmatics (Leech 1983) together with its sub-branches such as Politeness Theory (Brown and Levinson 1987, Watts 2003), Speech Act theory (Gass 2006); and Rapport Management (Spencer-Oatey 2000). In fact, the elements of Interactional Competence within Communicative Competence (Celce-Murcia 2007) rely largely on the interpersonal strategies and principles of Speech Acts theory and Politeness theory. What these theories have contributed to the teaching of the evaluative aspect of language is mainly a proposal of tactical interpersonal principles. For instance, one of the positive politeness principles outlined in Brown and Levinson $(1987,102)$ was 'Claim common ground'. This principle was extended into more delicate linguistic strategies such as 'convey $\mathrm{X}$ is admirable, interesting', which is then extended into three more refined strategies which are (1) 'Notice to Hearer (his interests, wants, needs, goods)', (2) 'Exaggerate (approval, interest, sympathy with Hearer), and (3) 'Intensify interest to Hearer'. Although the strategies proposed in Politeness Theory attend to people's attitudes and emotions, they do not deal with the comprehensiveness of different types of Attitude and particularly not with systematic linguistic resources for expressing these types of Attitude. Effective language teaching sometimes requires explicit language instructions which benefit from a detailed framework of language resources for expressing different types of Attitude rather than merely strategies and principles (de Silva Joyce and Feez 2012). What the Appraisal framework developed by Martin and White (2005) offers is a detailed and delicate account of different types of Attitude and linguistic strategies for realising Attitude in specific ways. For example, instead of proposing to language learners a politeness strategy that they need to pay 'Notice to Hearer (his interests, wants, needs and goods)' (Brown and S.C. Levinson 1987, 102), the Appraisal framework actually has a more comprehensive scope, outlining all kinds of attitude (including Affect, Judgement and Appreciation) rather than only 'interest, wants, needs and goods' with linguistic resources to realize these attitudes. The Appraisal framework also provides specific linguistic strategies to amplify attitude such as using 'Semantic Infusion', 'Isolation' and 'Repetition' for Intensification of Process and Quality (i.e. the Graduation system), which is a much more comprehensive and systematic than only outlining principles and strategies to language learners that they should 'exaggerate' and 'intensify' their feelings if they want to perform 'positive politeness' (Brown and S.C. Levinson 1987, 102). The robustness of the Appraisal framework in language teaching and learning warrants a refinement that could make the framework a powerful language teaching tool tailored for specific 
language needs of a particular cohort of learners; and the beauty of the Appraisal framework is that it is based on a solid theoretical ground of Systemic Functional Linguistics that allows refinements for different cultural and situational contexts. The current research has developed a refined Appraisal framework which can be used to prepare international students for participation in oral discussion or casual conversations (cultural context) about topics that any of them would encounter when living and studying in Australia, which are topics about their everyday life, their academic experience and their professional standing (situational contexts). Within the scope of this paper, the focus will be on refinements of the Attitude system. The following section reviews the basic representation of the Appraisal framework as a whole and the delicate system of Attitude.

The basic representation of the Appraisal framework is presented in Figure 1.

Overall, the Appraisal framework developed by Martin (2000), Martin and Rose (2003) and Martin and White (2005) provides a systematic account of language resources for expressing emotions and attitudes (Attitude), the sources of evaluation and the play of voices within and across texts (Engagement), as well as the amplification of both Attitude and the degree of Engagement (Graduation).

The Attitude system, a central element of the Appraisal framework, consists of three categories: Affect, Judgement and Appreciation (Martin and White 2005). Affect refers to language resources for expressing emotions. Judgement consists of language resources for evaluating people's behaviors. Appreciation deals with the evaluation of 'things'- 'things we make and performances we give.... and natural phenomena' (Martin and White 2005, 56). In general, Attitude can be expressed implicitly (invoked) or explicitly (inscribed) as positive or negative. The three sub-systems of Attitude are presented in Figure 2, Figure 3 and Figure 4 respectively with examples of their lexical instantiations.

Since its establishment, the Appraisal framework has been applied extensively to explore the evaluative aspect of language in a wide range of contexts including educational (Macken-Horarik 2003, Macken-Horarik, Love, and Unsworth 2011, Hood 2010, Macken-Horarik and Isaac 2014), professional (Lipovsky 2008, 2013) and political (Miller 2007) contexts. In addition to the application of the Appraisal framework in dealing with texts in the written mode, it has also been applied to analyse texts in the

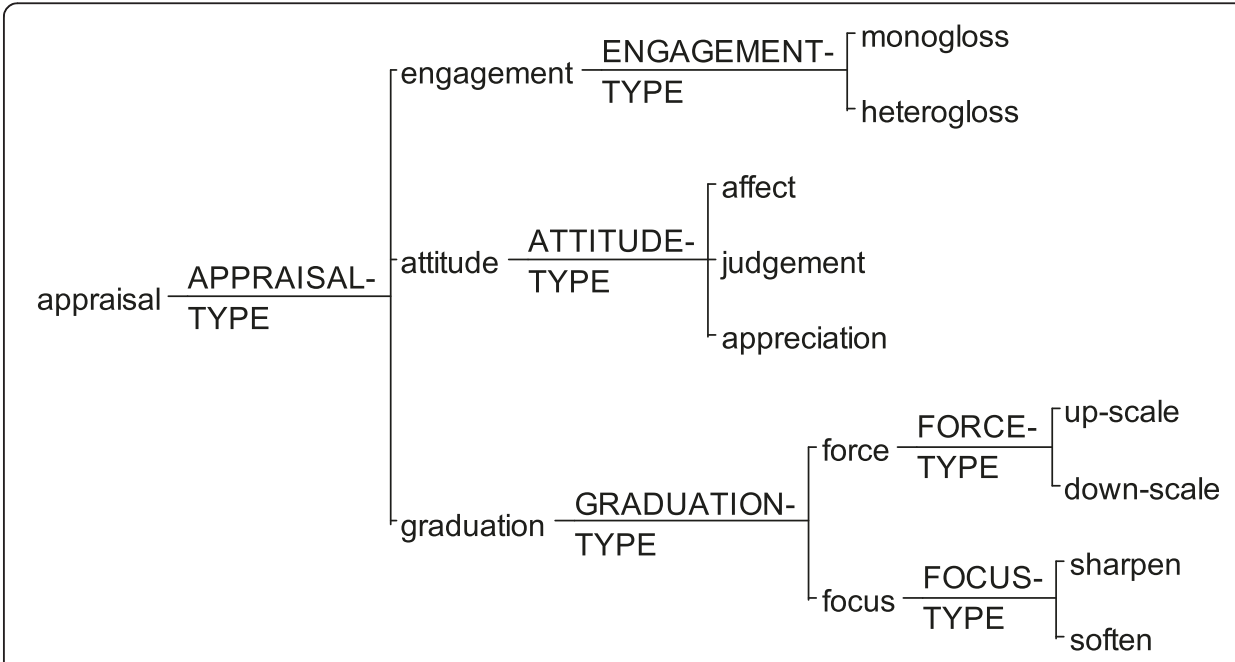

Figure 1 An overview of Appraisal resources (Adapted from Martin and White (2005)). 


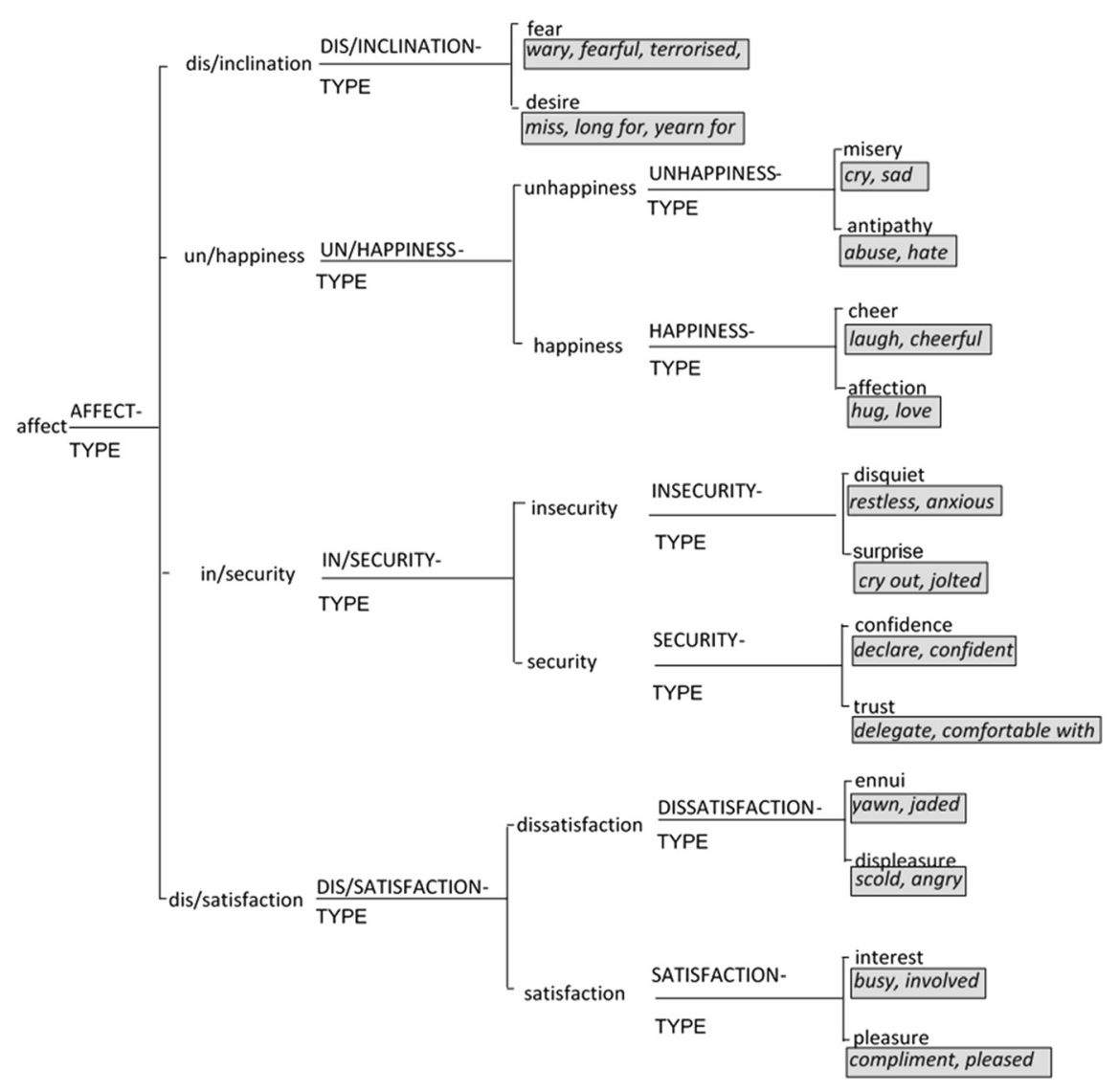

Figure 2 The Affect system and its lexical instantiations (Martin and White 2005, 51).

spoken mode (Adendorff and de Klerk 2005, Caldwell 2009, Becker 2009, Hood and Forey 2008, Eggins and Slade 1997, Eggins 2000) and multimodal mode (Unsworth 2013, Economou 2006, 2009, 2012, Swain 2012). Despite having been very powerfully used as a tool to understand and enhance the expressions of evaluative stance in texts of different modes, the Appraisal framework, according to Martin and White (2005), should be seen as an on-going project with issues still to be solved:

'...our maps of feelings (for affect, judgement and appreciation) have to be treated at this stage as hypotheses about the organization of the relevant meanings-offered as a challenge to those concerned with developing appropriate reasoning...' (Martin and

White 2005, 46)

In fact, since its establishment, the Appraisal framework has evolved with refinements and modifications that have resulted from detailed investigation of evaluative language in specific contexts. Examples for these refinements in different contexts include Bednarek (2008) refining the theorisation of the category of Affect based on her corpus data including conversation, academic writing and news reportage; Hood (2010) extending the system of Graduation based on her analysis of research articles; Hao and Humphrey (2012) elaborating on the category of Appreciation in the context of Biology experimental reports, Hommerberg and Don (2014) extending the category of Appreciation in the wine 


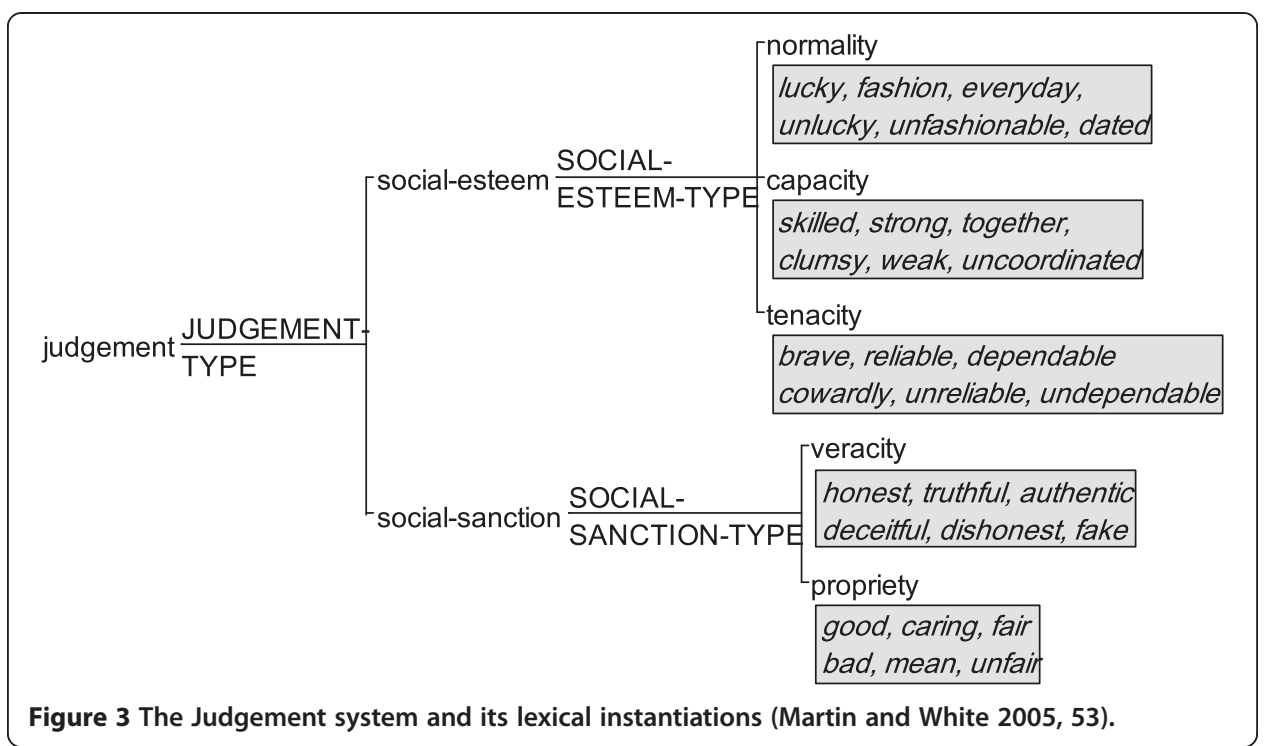

appreciation context and White (2012) extending the category of Judgement in the context of a French and English translational work of a cartoon.

The aim of this paper is to contribute to the on-going development of the Appraisal framework, particularly in terms of the system of Attitude, in contexts that international students from all language backgrounds are usually involved in. For international students, it is very common that they have casual conversations or formal oral discussions about issues relating to their personal everyday life experience and their academic and professional concerns as these topics are closely related to their security and well-being when living and studying overseas, and also their academic performance

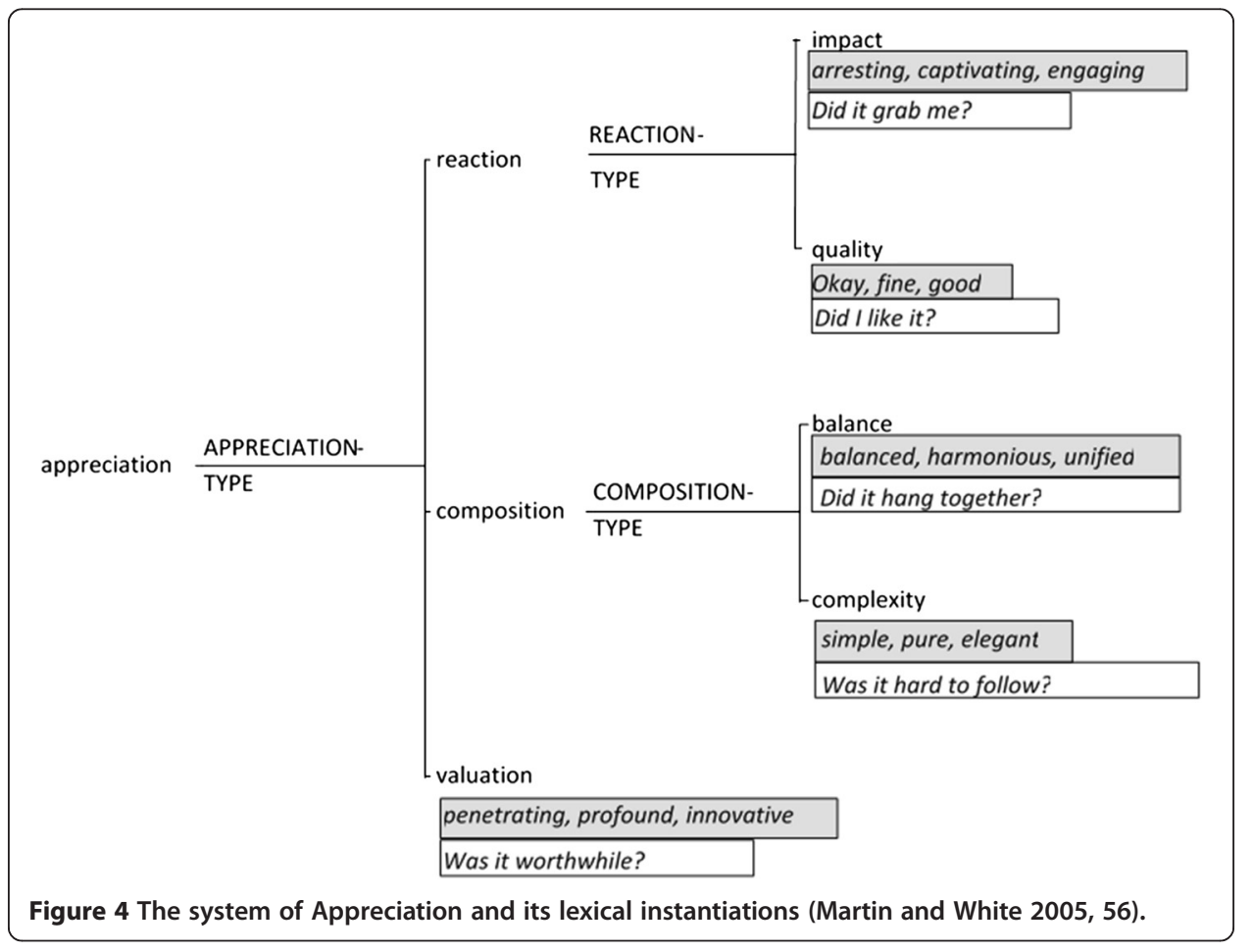


and their concerns about their current or future career. In discussing these topics, the capacity to express an evaluative stance effectively is essential. It not only allows international students to precisely express their needs and concerns in a new living and studying environment about things that matter to them everyday and to communicate and respond to the purposes of discussions appropriately but also to build solidarity and inter-subjective rapport, which is very important for their acculturation process and their security in a new country. This paper proposes an extension of a more delicate framework for expressions of Attitude that can be used as a tool for enhancing the precision in attitudinal meaning expressions in semi-casual oral discussions involving three of the topics of particular and frequent interest to international students mentioned above. The article begins with the Methods section providing a brief description of the approach taken in the study. The Results section provides the basis for a proposal for modifications to the Attitude system in all three categories of Affect, Judgement and Appreciation, which is developed in the Discussion section. The paper concludes with the significance of the re-theorisation and modifications of the framework in linguistic research and language teaching.

\section{Methods}

\section{Design of the study}

This paper reports part of a larger study using Systemic Functional Linguistics, and employing the Appraisal framework to analyse evaluative language patterns deployed in semi-casual discussions about topics of particular interest to international students. The primary purpose of the study was to investigate Vietnamese students' repertoires of English and Vietnamese Appraisal resources in oral discussions about popular topics that they are usually involved in when living and studying in Australia and their common difficulties in expressions of Attitude in English. The research results have implications for language teaching, testing and assessment as well as theoretical implications in further refinements of the Martin and White Appraisal framework. In this paper the focus is on refinements to the Appraisal framework in the context of English language use.

Before the main study was carried out, a small scale pilot study was conducted to explore the approaches to participant recruitment, data collection and data analysis. As a result of this pilot study, an adapted Appraisal system was generated as the coding scheme for the main study, and this adaptation is the first stage in the proposed modifications to the Appraisal framework that are reported in this paper. The other modifications were generated as a result of the data analysis for the main study

\section{Participants}

The participants in the research were sixteen Vietnamese graduate students including both male and female who were enrolled in a variety of disciplines in universities in Sydney. Most of these participants had the same length of time living in Australia and similar educational backgrounds. Their English proficiency level was classified as competent or high competent users of English with their IELTS score or equivalent ranging from 6.5 to 8, which represents the range of English language proficiency level of most international students in Australia. 


\section{Data collection}

For data collection, participants were rotated through eight groups: four groups having Vietnamese conversations and four groups having English conversations. Each discussion group consisted of four participants with an equal number of male and female students. Each participant appeared in two conversations (one in Vietnamese and one in English). The discussions in both languages were about the same topics including their personal experience about living in Australia, their judgement of their lecturers' performances, appreciation of the enrollment process, the assessment of students' performance, and their professional standing in Vietnam. As all of these participants were graduate students who had not known each other previously, effects on linguistic choices caused by different levels of solidarity could be minimized. However, it was not possible to control for potential effects of different ages and gender of the participants. The length of the interactions in the English and Vietnamese conversations was the same (approximately one hour each). All the talks were video and audio recorded. For the purpose of this research, the audio data was the main source.

\section{Data analysis}

The audio data was transcribed manually for wordings using a conversation transcription convention adapted from Eggins and Slade (1997). The deployment of evaluative language in English and Vietnamese discussions was analysed from the Vietnamese and English transcripts, using the Appraisal framework (as adapted following the pilot study) for Attitude and Graduation. The category of Engagement was not explored in this research as it was anticipated that Engagement was not a major evaluative category in text types such as casual conversations and oral discussions. Due to the focus in this paper on a proposal for refinement of the Attitude system, the adapted framework for Graduation is not presented.

\section{Results and discussion}

As briefly mentioned, the determination of the proposed refinements to the Attitude system occurred in two stages. The first stage involved the pilot study trialing the Martin and White Attitude system (2005) (which will be referred to as the 'original Attitude system' hereafter) and a thorough and critical review of the literature on the refinements of the original Attitude system. As there were issues arising from the application of the original framework in analysis of attitudinal language resources in the pilot study, the critical literature review was conducted after that in an attempt to seek solutions. There were issues relating to both Affect and Appreciation such as the negative polarity assignment for Surprise, the irrealis and realis trigger basis for the categorisation of Fear under Dis/Inclination (Affect) and the unclear distinction between Impact and Quality in the system of Appreciation. As a result of the critical review following the pilot study, an adapted Attitude system which addressed the issues arising from the pilot study was generated to be used as the coding scheme of the main study. The second process of refining the original Attitude system occurred during the application of the adapted framework to analyse the main study data, which resulted in a second set of modifications of the original Attitude system. As the main study had a very large amount of data (four times as much as the pilot study), the data analysis in 
the second step using the modified framework confirmed the validity of the modifications made to Affect in the first step. Moreover, the amount of data was also sufficient to observe recurring patterns of more delicate sub-types of Appreciation and Judgement, enabling the proposal for new Appreciation and Judgement sub-types. In this section, the first and second steps of modifications will be presented in part 1 and part 2 respectively.

Part 1: Issues with the original Attitude system arising from the pilot study and proposal of the first modification

In applying the original Attitude system to analysing attitudinal meaning in the English discussions by the Vietnamese students, issues with categorisation arose with the subsystems of Affect and Appreciation. In following section, these issues will be discussed, followed by suggestions for adaptation of the respective systems.

Issues with Affect and the generation of the adapted Affect system

The employment of Affect to analyse evaluative language in the English discussions in the pilot study revealed that there were issues with the theorisation of this sub-system of Attitude including (a) the negative polarity assignment of Affect-Insecurity: Surprise, and (b) the typology of Affect types.

\section{a. Issues with the negative polarity assignment of Affect-Insecurity: Surprise}

As can be seen from the original Attitude system in Figure 2, Surprise was classified under Insecurity, representing a negative type of feeling. However, the feeling of Surprise can be related to both positive and negative feelings as found in the pilot study data. Consider the two instances of the feeling 'Surprise':

(1) I was very surprised to receive my results. I was really lucky to get such high marks.

(2) I was shocked really shocked when I saw them hugging and kissing each other (right in front of me).

It seemed obvious that in the second instance, the instantiation 'shocked' can be coded in the Insecurity category as it instantiated the negative feeling of Disquiet. However, it is not easy to do the same with the instantiation 'surprised' in the first instance as the co-text suggests that the Surprise feeling in the first instance is associated with the positive feeling of Happiness-Cheer.

A close examination of related literature revealed that Bednarek (2008) found the same issue with Surprise in her corpus data. Bednarek (2008) suggested establishing Surprise as an independent category as it is an independent type of feeling and doing so can avoid assigning the negative polarity to it as in the original Attitude system. However, with regards to the dichotomous feature of the system network, in the case of the Appraisal framework, for example, a category could be extended into positive and negative choices. For example, the category of In/Security can be extended into the positive and negative sub-categories of Confident and Disquiet. However, this dichotomous feature cannot be applied to Surprise if it is established as an independent category because there is no such feeling as 'not surprise'. 
Since the feeling of Surprise could not be subsumed under Insecurity, and could not be readily established as an independent Affect type, it was proposed that the feeling of Surprise could be dealt with as a resource invoking other Attitude types such as the Affect types of Un/Happiness and In/Security as in instances (1) and (2) above. Examples (3) and (4) extracted from the data further illustrate how the meanings of Surprise could be dealt with. The extracts may contain non-standard English expressions. Contextual information is provided in parentheses.

(3) I'm very surprised to receive his present, very kind man.

(Invoked: +ve Aff: Happiness-Cheer)

(4) (Ha shared her accommodation with three other girls from Hanoi. Among them, Ha didn't like flowers so she decided not to share the money the other girls paid for the flowers to decorate the house. Therefore, the three girls who paid for the flowers covered the flowers with a blanket so that Ha couldn't share the view of the flowers because she didn't share the money. In the following discussion, Lien, Hung and Huyen were commenting on that behaviour).

Lien: ==who would hide the flowers away in a blanket just because she didn't want to share the view of the flowers with the housemates who didn't contribute money to buy the flowers!

Hung: Oh my god! What they did is a surprise for me. [laugh]

(Invoked: -ve Aff: Disquiet)

Huyen: I'm really shocked to hear that. I would question 'Is that Hanoi culture? (Invoked: -ve Aff: Insecurity- Disquiet).

Lien: I think so.

In instance (3), 'surprise' invokes positive Affect-Happiness-Cheer. In (4), 'surprise' and 'shocked' invoked negative Affect-Insecurity-Disquiet.

In short, Surprise seems to be a very special type of feeling in that, unlike other Affect types in the original Attitude system, it does not have an opposite feeling. The polarity of Surprise has to be examined closely in relation to the co-text and therefore it cannot be placed in the negative or positive category in the Affect system. As far as the authors are aware, to date the issues with Surprise have not been resolved in satisfactory fashion. In view of this, our proposal based on the current research is to deal with Surprise as a resource invoking other Attitude types. Since In the system network Surprise is necessarily removed from Insecurity, this category needs to be re-conceptualized and this revised approach to In/Security will be discussed in section (b) below.

\section{b. Issues with the categorisation of Dis/inclination-fear and In/security-surprise}

The second issue with the Affect system in the original Attitude framework was the categorisation of Fear under Dis/inclination. As shown in Figure 2, Dis/inclination has 
two sub-categories: Fear (negative) and Desire (positive). It is understandable that Fear and Desire are categorised under Dis/Inclination due to their commonality of having irrealis triggers, which seemed to be the basis for the categorisation of Fear under Disinclination as demonstrated in examples (5) and (6), in which the irrealis trigger for the Desire feeling instantiated by 'suggest' in example (5) is 'a change of this organisation' and for the Fear feeling instantiated by 'feared' in example (6) is 'leaving'.

(5) We suggest a change of the structure of this organisation.

(6) The captain feared leaving (Martin and White 2005, p.48).

However, Fear does not only have irrealis triggers but also has realis triggers as many instances in the pilot study data demonstrated. Consider examples (7) and (8):

(7) Like many other students I was very scared by the pressure of exams.

(8) Speaking in the public often makes people very scared. It is nerve-wracking for me too.

In addition, in instances (7) and (8) above, the meaning that Fear realises is more skewed towards Insecurity-Disquiet than towards Disinclination. Therefore, the categorisation of Fear under Dis/Inclination is problematic. To deal with this issue, Fear could be removed from Dis/Inclination to be merged with Insecurity- Disquiet. This solution was also found in Bednarek (2008). On removing Fear, the subtype of Dis/inclination will be impaired as only 'Desire' will remain. Bednarek (2008) proposed to have 'Non-desire' in place of 'Fear', which would be a perfect opposition of 'Desire' except for the lexically awkward nature of the term. So far there has not been a satisfactory taxonomic category for the counterpart of Desire in the current literature, therefore 'Non-Desire' as proposed by Bednarek (2008) was accepted in the coding scheme of this study. Examples of some lexical instantiations of Non-desire could include 'ignore', 'neglect', 'reluctant', 'refuse to', and 'disinclined'. Examples of some lexical instantiations of Desire are as described in Martin and White $(2005,48)$ including 'suggest', 'long for' and 'miss'. Up to this point, the representation of the Affect system with modifications is displayed in Figure 5, where Non-Desire replaced Fear in the category of Dis/Inclination. Fear is merged with Disquiet in the category of $\mathrm{In} /$ Security.

As seen from Figure 5, In/security in the original Attitude system has two subtypes positive feeling as 'Security' and negative feeling as 'Insecurity'. 'Security' is sub-categorised into 'Confidence' and 'Trust'. 'Insecurity' is further sub-categorised into 'Disquiet' and 'Surprise'. As discussed in section (a) above, Surprise cannot be categorised as a negative feeling. Moreover, as Surprise is an independent type of feeling, it only inscribes the feeling of Surprise rather than being considered as inscribing Insecurity. On the basis of the above argument, Surprise is removed from the category of Insecurity, which makes Insecurity impaired because only Disquiet remains as the contrast of the positive feeling Confidence. In the place of 'Surprise', Bednarek (2008) suggested having 'Distrust', thus, the category of Insecurity would then consist of 'Disquiet' and 'Distrust' and the category of Security would consist of 'Confidence' and 'Trust', creating the two direct positive-negative opposing pairs of 'Confidence'-'Disquiet' and 'Trust' 


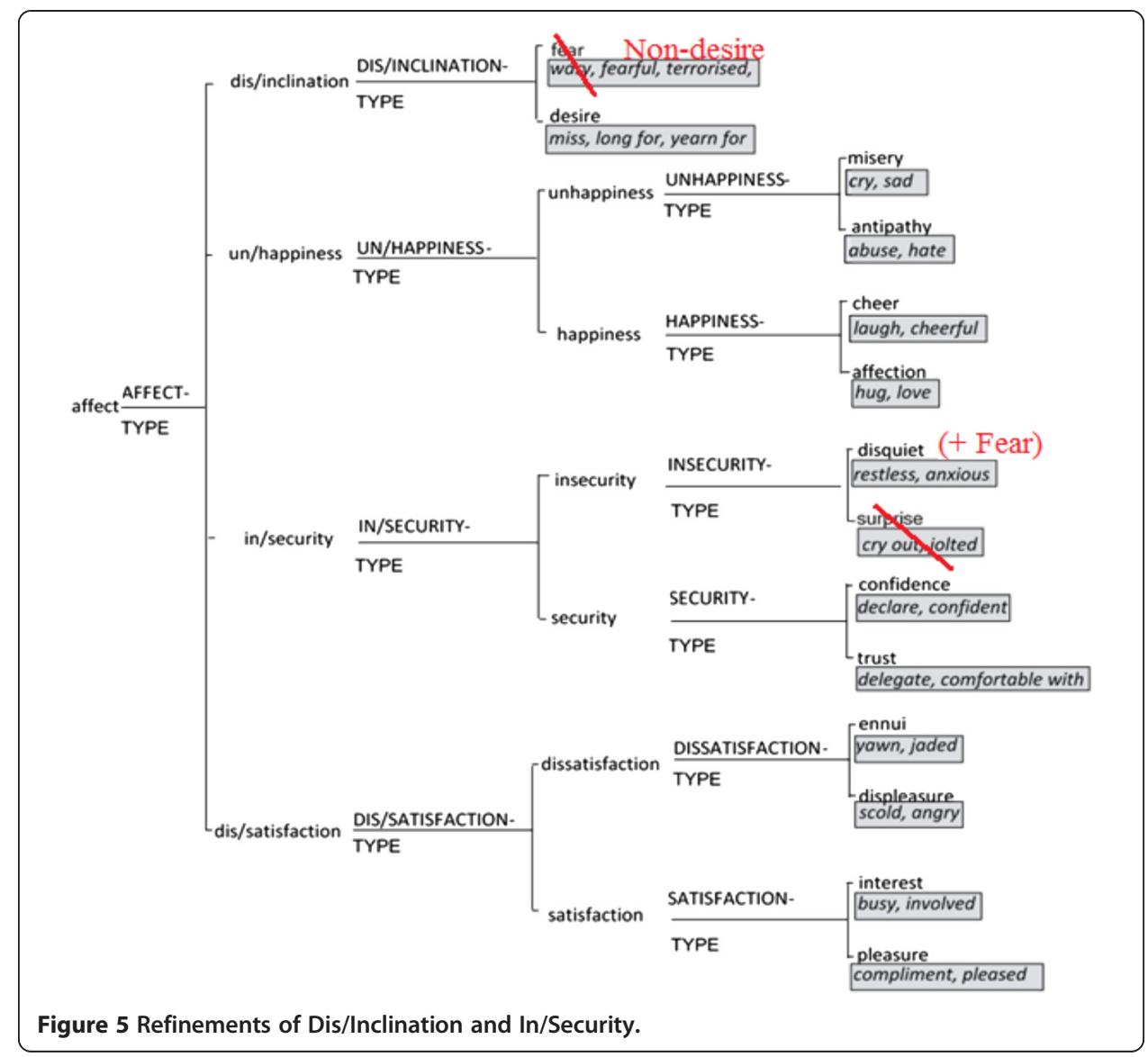

and 'Distrust'. Lexical instantiations of Distrust according to Bednarek (2008) include 'reserve', 'suspicion', 'doubt/doubtful', 'hesitate' and 'reluctant'. This categorisation worked well for the data analysis of the main study. Table 1 exemplifies instantiations of In/Security subtypes from the data:

Taking on Bednarek's proposal of Distrust in place of Surprise, the first stage of modifications to the Affect system is presented in Figure 6.

The modified Affect system as presented in Figure 6 was generated in response to issues arising from the application of the original Affect system through critical application of the results of previous research, mainly that of Bednarek (2008). In the adapted Affect system, no changes were made to Un/happiness and Dis/satisfaction. Only Dis/ inclination and In/security were modified. The refined system was then applied in the

Table 1 Instances of in/security sub-types

\begin{tabular}{|c|c|}
\hline Disquiet & Confidence \\
\hline Many students are very stressed about exams. & $\begin{array}{l}\text { Because the task does not give a mark, so I have } \\
\text { no pressure at all. }\end{array}$ \\
\hline $\begin{array}{l}\text { I was very nervous because I didn't know how to } \\
\text { write, how to attend exams. }\end{array}$ & I felt quite confident when applying for jobs in companies. \\
\hline Distrust & Trust \\
\hline You can never trust your lecturer. & I thought I was very optimistic about my job opportunities. \\
\hline $\begin{array}{l}\text { First, I was reluctant to ask but he was very } \\
\text { kind and helpful to me. }\end{array}$ & I trusted in whatever the lecturer told us. \\
\hline
\end{tabular}




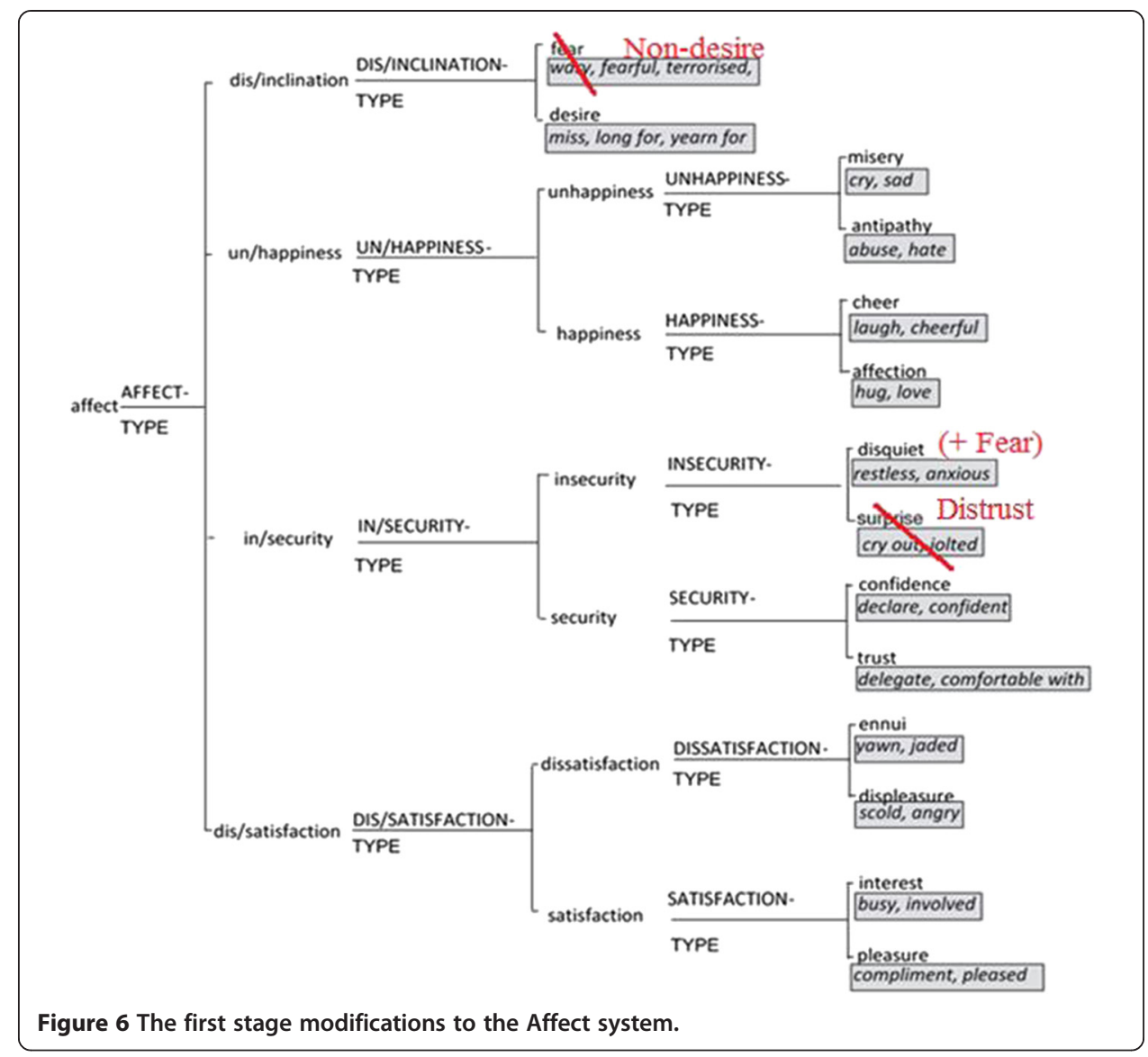

data analysis of the main study and was shown to account very well for the coding of evaluative language.

Issues with appreciation and the re-theorisation of appreciation

In the original Attitude system as shown in Figure 4, Appreciation is sub-classified as Reaction, Composition and Valuation (Martin and White 2005). These categories can be further sub-classified with Impact and Quality as more delicate realisations of Reaction, and Balance and Complexity as more delicate realisations of Composition. Unlike Reaction and Composition, Valuation was not extended into more delicate choices. Reaction refers to people's evaluation of the Impact of things and also the evaluation of the Quality of things. Composition deals with the evaluation of the Balance and Complexity of things. Valuation is concerned with the 'value' or significance of things.

During the application of the original Appreciation system in the analysis of the pilot study data, several issues relating to the distinction between Impact and Quality within Reaction, and the theorisation of Composition and Valuation arose. In the following section, these issues will be discussed and modifications to the original Appreciation system will be proposed.

\section{a. Issues with reaction and the re-theorisation of reaction}

The issue with Reaction was the theorisation of the category itself, making it hard for the coding of the pilot study data from the outset. In Martin and White (2005), within 
the category of Reaction, the two delicate choices of Impact and Quality were distinguished only by their probe questions and lexical instantiations, which are not sufficiently helpful. The probe question for Quality 'Did I like it?' provokes an emotive reaction, which can be confused with Impact, the probe question of which also provokes an emotive reaction 'Did it grab me?'. It appears that the only difference between the two probe questions is that for Impact, the appraiser is passive while for Quality, the appraiser is active. However, the examples of lexical items representing these two types of meanings provided by Martin and White $(2005,56)$ did not reflect this and were not sufficiently clearly illustrative due to the lack of context. For example, in Table 2.8 on page 56 in Martin and White (2005), 'good' was displayed as an example of Reaction-Quality. In the pilot study data, 'good' was found to realise both ReactionImpact and Reaction-Quality as in instances (9) and (10).

(9) Dai: When I first arrived in Seoul, I went 'Wow! This is good'.

(10) Dai: Their infrastructure was very good, very high quality.

For instances like instance (9), the probe questions distinguishing Impact (Did it grab me?) and Quality (Did I like it?) are not sufficiently helpful to determine whether 'good' realises Impact or Quality. The way to think about the distinction between Impact and Quality proposed in this paper is that Impact refers to an interactive emotive response to things while Quality refers to a designated standard. A probe question for Quality could be 'Does it indicate a particular standard?' With this distinction, it is quite obvious to see that 'good' in instance (9) realises Impact and in instance (10) realises Quality. More data from the pilot study support this distinction as exemplified in instances (11) and (12) below.

(11) The very first impressive (+ve Impact) thing for me when I arrived in Cambodia was that the women were very beautiful (+ve Quality).

(12) We are a very very poor (-ve Quality) country.

With the proposed definitions of Quality and Impact, it appears that Quality would no longer fit under Reaction, which provokes an emotional reaction just as Impact does. The analysis of sufficient amount of data in the main study supports the need for a rearrangement of Quality and Impact in the framework, which is detailed in Part 2.

\section{b. Issues with the theorisation of composition}

The issue with the second category of Appreciation, Composition, is that the probe questions for the two subtypes, Balance (Did it hang together?) and Complexity (Was it hard to follow?) and examples of lexical instantiations seem more oriented to 'textual organisation' (57) rather than to 'things we make', 'performances we give' and 'natural phenomenon' (Martin and White 2005, 56). Some lexical instantiations of Balance include 'balanced, unified, consistent, willowy' (positive) and 'unbalanced, disorganised, distorted' (negative). Some examples of Complexity include 'simple, intricate, detailed' (positive) and 'ornate, extravagant, unclear, plain' (negative)'. The meaning of Balance 
and Complexity can actually extend beyond just textual organisation. They can deal with the balanced and complex nature of entities, phenomena or human activities. Instances from (13) to (15) taken from the pilot data illustrate this point. The instances may contain non-standard English expressions.

(13) Basically I'm a music teacher. So it's different field compare with other. It's interesting too, but it's challenge.

(14) ... a good teacher is a teacher who can make everything easier to understand

(15) then maybe people think it's quite hard to mark it (a music performance) but we set a lot of criteria which is very helpful when you (do the) marking.

In the three instances above, the lexical instantiations of Complexity- 'challenge', 'easier' and 'hard' refer to the complexity of human activities, which respectively are 'teaching music', 'understanding lessons' and 'marking a music performance'. Therefore, it is necessary to consider the co-text in order to appreciate the manner in which these lexical instantiations relate to contexts other than linguistic texts. The inclusion of this kind of contextual information in the Martin and White account would clarify the broader scope of the concepts of complexity and balance. The re-theorisation of the scope of Complexity and Balance enabled more precise coding of Complexity and Balance in other fields than those entailed in the Martin and White (2005) account. In the current research, this re-theorisation allows the coding of data about the complexity of academic work and professional activities, which occurred very frequently in the discussions.

\section{c. Issues with valuation}

The issue with the last category of Appreciation, Valuation, is that this category does not have a firm definition, except for the probe question 'Was it worthwhile?", which is very broad and hence the semantic range of the examples of lexical instantiations is too diverse. Data from the pilot study suggested more delicate extension of Valuation. Consider instances (16) and (17) extracted from the pilot study.

(16) I agree with Tuan that marketing is very very important and it is crucial to have a lecturer who has a lot of experience working in the field.

(17) Living with international students has both advantages (Benefit) and disadvantages .

(18) Tropical storms are always very destructive.

In the three instances above, the broad semantic range of the four realisations of Valuation suggested that the meaning of this Appreciation subtype can actually be further sub-categorised into more delicate groups, dealing with the appreciation of 'importance' (Significance) and assessing Harm (e.g. destructive) or Benefit (e.g. helpful) as (White 1998) and (Humphrey 2008, 147) proposed. The proposed probe question for Significance would be 'Was it important?' and for Benefit/Harm would be 'Did it 
enhance or damage?' This obviates the role of the original probe question of Valuation (Was it worthwhile?) and facilitates a more precise coding of this aspect of Appreciation. More examples from the pilot study confirmed the validity of this extension of Valuation as shown in instances (19) and (20) below.

(19) Instances of Significance

The subjects are very basic for Economics and Finance students, so at Master's level with a few years of experience, I think they are not necessary for me.

(-ve Appreciation: Significance)

(20) Instances of Benefit/Harm

(a) The course is very useful for my career. (Benefit)

\section{d. The first modifications to the network of appreciation}

Taking into account the preliminary issues with the system of Appreciation arising from the pilot study, the adapted network shown in Figure 7 was formulated. In this adapted system, the two choices of Reaction (i.e. Impact and Quality) remained the same. From the results of the pilot study and critical literature review, a new definition and probe question were added to the system to facilitate an easier distinction between Impact and Quality. In respect of Composition, the two options of Balance and Complexity remain the same, noting that the values of Composition can extend beyond textual organisation. Regarding Valuation, the original category is further split into the two choices of Significance and Benefit/Harm. This adapted Appreciation system was used as the coding scheme in the main study.

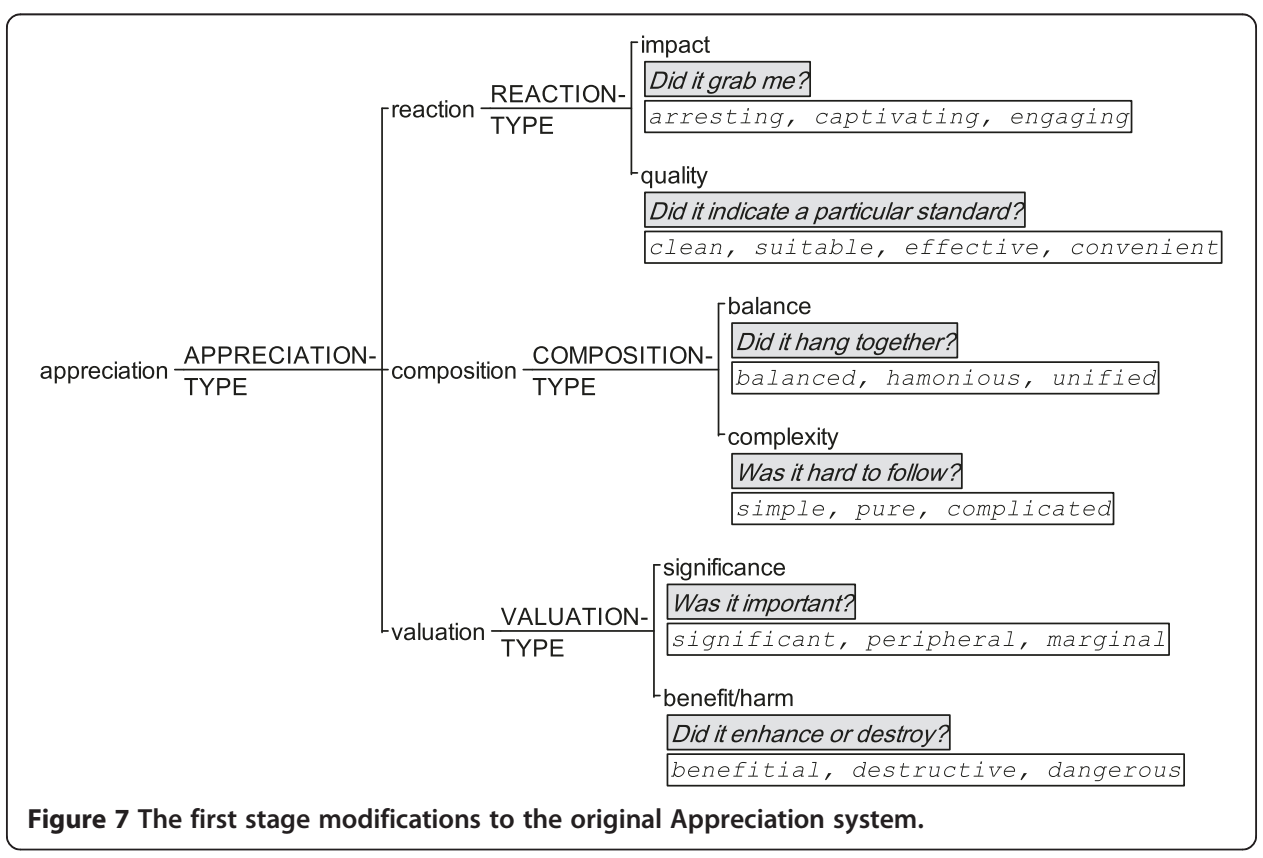


Part 2: Second stage modifications to the attitude system as a result of the main study The adapted system of Attitude incorporating modifications to Affect and Appreciation as discussed in part 1 above, and with Judgement unchanged, was used as a coding scheme for analysis of the main study data. Apart from the preliminary aim of examining the differences in the deployment of language resources for expressing attitudinal meaning in the English and Vietnamese discussions, the study also tested whether the adapted Attitude system was sufficiently robust to investigate evaluative meanings in this context or whether further refinement was needed to accommodate analysis of the data. The data analysis and the research findings indicated that the adapted system for Affect worked well for both the Vietnamese and English language data. However, the data analysis showed that the categories of Judgement and Appreciation warranted further refinements, which are discussed below.

\section{The refinements of judgement}

The analysis of evaluative language resources for expressing attitudinal meaning revealed that within the system of Judgement, the current theorisation of Judgement types of Tenacity, Propriety and Veracity could sufficiently accommodate the data. However, Normality and Capacity can be extended to include more delicate choices.

\section{a. Refinement of judgement-normality}

In Martin and White (2005), the meaning of Normality was explained simply as 'how unusual someone is' with the probe question 'How special?' In this study, however, it was noted that the range of realisations of Normality in both the English and Vietnamese data was very diverse in meaning as seen in Table 2 . The data suggests a possible re-

Table 2 Subcategories of normality

\begin{tabular}{|c|c|c|c|}
\hline $\begin{array}{l}\text { Subcategories of } \\
\text { normality }\end{array}$ & Polarity & $\begin{array}{l}\text { Lexical } \\
\text { instantiations }\end{array}$ & Instances of normality \\
\hline \multirow[t]{3}{*}{ Fortune } & + ve & may mắn & $\begin{array}{l}\text { Nhiều khi mình rộng rãi một tí thì em thấy... mình cũng } \\
\text { may mắn hơn, em tin vào điều đấy. }\end{array}$ \\
\hline & & lucky & $\begin{array}{l}\text { Sometimes when we are a bit (more) generous, we will be } \\
\text { much luckier, I believe so. }\end{array}$ \\
\hline & + ve & lucky & $\begin{array}{l}\text { But you know l'm quite lucky that I haven't have to face } \\
\text { with the very big problems with other people, yeah, so it's } \\
\text { very small things. }\end{array}$ \\
\hline \multirow[t]{4}{*}{ Reputation } & + ve & cấp cao & $\begin{array}{l}\text {...chỉ cần liên hệ với giám đốc công ty đã khó nói gì đến } \\
1 \text { vị quan chức cấp cao như thế. }\end{array}$ \\
\hline & & high-ranking & $\begin{array}{l}\text {...it's already difficult to contact a manager of a company, } \\
\text { not to mention such a high-ranking official. }\end{array}$ \\
\hline & $+v e$ & important & $\begin{array}{l}\text { In the interview, I also got very important person from } \\
\text { the council. }\end{array}$ \\
\hline & + ve & famous & He is a famous supervisor and a very busy man. \\
\hline \multirow[t]{4}{*}{$\begin{array}{l}\text { Behaviour } \\
\text { (customary } \\
\text { behaviours) }\end{array}$} & + ve & chung & $\begin{array}{l}\text { Khi mà vợ mình chưa sang ấy thì mình thích trong nhà } \\
\text { mình có phụ nữ. Thực ra mình nghĩ đấy là tâm lí chung } \\
\text { của mọi nam giới thôi. }\end{array}$ \\
\hline & & common & $\begin{array}{l}\text { When my wife hadn't come here yet, I liked to share the } \\
\text { accommodation with ladies. Actually I think that is the } \\
\text { common way of thinking of every man. }\end{array}$ \\
\hline & -ve & bị hâm & Nó đề ra một loạt quy định theo cái kiểu bị hâm. \\
\hline & & mentally abnormal & He set up a series of rules in a mentally abnormal way. \\
\hline
\end{tabular}


categorisation of Normality into three subcategories dealing with the meanings of Fortune, Reputation, and Behaviour. Most typical instances of each of these three categories from both the English and Vietnamese data are presented in Table 2.

\section{b. Refinement of judgement-capacity}

As its taxonomy suggests, Capacity as described in Martin and White (2005) refers to the judgement of how capable people are. The realisations of Capacity found in this study are so diverse in meaning that the data is suggestive of a more delicate typology for this category. Realisations of Capacity from both the Vietnamese and English data can be categorised into three groups: Mental Capacity, Material Capacity and Social Capacity. Mental Capacity refers to mental or cognitive performances and academic or professional skills. Material Capacity has to do with physical performance, physical and technical skills. Social Capacity refers to personal and interpersonal performances. All the instances from the data can fit into one of the three categories. Examples from the data analysis are shown in Tables 3, 4, and 5 .

\section{The refinements of appreciation}

The data analysis validated the modified theorisation of Appreciation as discussed in part 1, including the refined theorisation of Reaction (Impact and Quality), Composition and Valuation. Furthermore, the research findings also provided evidence for the extension of Quality to include more delicate subtypes and the refinement of the typology of Complexity within Composition.

\section{a. Refinement of appreciation-reaction}

The research findings provide an evidential basis for a number of refinements to be made to Reaction. Firstly, as indicated in the pilot study data, the findings of the main study confirmed that the proposed distinction between Impact and Quality as presented in part 1 was valid. The distinction that Impact refers to an interactive emotive response to things while Quality refers to a designated standard enabled a more

Table 3 Mental capacity (mental/cognitive performances and academic/professional skills)

\begin{tabular}{ll}
\hline Polarity & Instances of mental capacity \\
\hline Positive & Trong khi lợi thế của mình học thuộc rất tốt, vì thế cho nên mình chỉ cần tận dụng cái đó \\
mình đi thi thì không thành vấn đề. \\
While my advantage is learning by heart very well, so I need to make use of it when doing \\
exams then there will be no problems. \\
Ông giảng rất là hay. Ông ấy giảng về vũ trụ thậm chí ông hiểu biết sâu về Y học, về máy \\
X-quang như' thế nào. \\
He explained very interestingly. He explained about the space, he is even very knowledgeable \\
about Medicine and how the X-ray machine works. \\
I like this teacher because he's very intelligent, open-minded and he's humorous. \\
I know she's skillful, yeah, very professional. \\
Tại vì nó nhiều quá, không thể đọc hết được. \\
Because there was so much reading, (I) couldn't read it all. \\
Đến khi mình không làm thì không nhớ được nữa. \\
When we don't do it, we can't remember it anymore. \\
My nephew also- I think that my nephews- my kids in my family they don't have any ability \\
to play music. \\
If he's not a real journalist, he cannot teach us how to write an article.
\end{tabular}


Table 4 Material capacity (physical performance, physical and technical skills)

\begin{tabular}{ll}
\hline Polarity & Instances of material capacity \\
\hline Positive & Làm xôi xéo cũng thế thôi. Con bé cũng khéo. \\
& Making 'xôi xéo' (mung bean sticky rice) is just like that. She is dexterous. \\
& Và cô giáo thì thực sự là 1 người rất là năng động trong lớp....Em thấy thích giáo viên hoạt \\
bát 1 chút, đi lại, nói chuyên và trao đổi vân vân. \\
And the teacher is really a very active person in the class... I feel I like teachers who are a bit \\
vivacious, walking around, talking, discussing, etc.. \\
...provided that I could clean and I do something clean so it doesn't really matter. \\
I was living with a very big Australian guy and he drinks like 24 bottle at night and not drunk. \\
(...). He is ok but I'm not ok. [laugh] \\
Nhiều khi có thể là lúc bạn học rất tốt nhưng mà đến ngày thi chẳng hạn bạn lăn ra ốm thì \\
rất là thiệt thòi cho bạn. \\
Sometimes while you learn very well but when the exam day comes for example you fall ill, that \\
will be very disadvantageous for you. \\
nếu mà lúc ốm đau ấy, nhiều khi mình đã rất là khổ sở rồi lại bảo mình phải nói cả tiếng Anh \\
thì đó là cả 1 vấn đề. \\
If when (we are) sick, sometimes we are already miserable, yet being required to speak in English is \\
a whole problem. \\
Lúc đó mình đã xỉu rồi làm thế nào để mà có thể làm gì tiếp theo được? \\
At that time we will have already fainted, how can we do anything else? \\
I was very ill at that time, I cannot stand up or look after myself. \\
I was living with a very big Australian guy and he drinks like 24 bottle at night and not \\
drunk. (...). He is ok but l'm not ok. [laugh]
\end{tabular}

consistent coding of these two categories of Appreciation. Instances of Impact coded under the new theorisation in both the English and Vietnamese data are presented in Table 6.

Secondly, the data also confirmed the basis for a more delicate delineation of Quality into four sub-categories: Aesthetics, Appropriateness, Effectiveness and Convenience. Note that the nature of Appreciation is field specific (Christie and Martin 2005) and accordingly the account of these resources may be extended as linguists and educators

Table 5 Social capacity (personal and interpersonal performances)

\begin{tabular}{ll}
\hline Polarity & Instances of social capacity \\
\hline Positive & Ỏ với người Việt thì vui, dễ hiểu nhau hơn. \\
& Living with Vietnamese people is fun, easier to understand each other. \\
& Mỗi người cũng giảm bớt đi một tí cái yêu cầu của mình thì sống được vói nhau. \\
& If each person decreases their demand a little, we will be able to live together. \\
& Thế sau một thời gian....nó thấy rõ sự khó chịu của mình. Nó cũng cực kỳ tâm lý, nó hỏi \\
& 'Mày không thích à?' \\
& (After some time, she clearly felt my annoyance. She was extremely understanding, she asked me \\
& You don't like it, do you?') \\
& (A good flat-mate) 'can be socially', easy to be with and shouldn't be drinking too much.' \\
& Nhưng mà vì sự khác biệt về văn hóa hóa làm cho đôi khi không hiểu nhau, lại không thể \\
& nói lại cho nhau để hiêu hơn ....thậm chí làm cho tình huông ngày càng tội tện. \\
& But the difference in culture sometimes makes (us) not understand each other yet unable to \\
& communicate in a way that makes each other understand better will even make the situation \\
& worse and worse. \\
I think she's honest, naive, and very helpful, sometimes childish.
\end{tabular}

${ }^{1}$ Non-standard expression of English. A standard expression would be "sociable". 
Table 6 Instances of Impact (referring to an interactive emotive response to things)

\begin{tabular}{|c|c|}
\hline Polarity & Instances of impact \\
\hline \multirow[t]{3}{*}{ Positive } & I think it's wonderful to stay together. \\
\hline & Trang thấy Finance nó cực kỳ thú vị. \\
\hline & I find Finance extremely interesting. \\
\hline \multirow[t]{3}{*}{ Negative } & $\begin{array}{l}\text { And they return all Pass, no C, no D, no HD. Oh my God! Unbelievable! This's such a... it's } \\
\text { very stressful. }\end{array}$ \\
\hline & ...công việc rất là mệt mỏi và căng thẳng. \\
\hline & The job is very mentally wearing and stressful. \\
\hline
\end{tabular}

work on Appraisal in different fields. The refinements proposed in this paper are based on the fields represented in the discussion data and instances of the more delicate Quality sub-categories are exemplified in Table 7.

The meaning of all the instances in these Quality sub-groups did not concern Reaction or overall impression of an entity as originally described in the Appraisal framework; rather it expresses the delicacy in the appreciation of the quality of an entity. With this distinction, it seems appropriate from the results of the analyses to remove Quality from Reaction and make it a separate category at the same level as Reaction. Since Impact and Reaction refer to the same type of evaluative meaning, the term 'Impact' is retained to replace Reaction. The proposed new Appreciation system as recategorised is shown in in Figure 8.

\section{b. Refinement of appreciation- composition: complexity}

Another refinement to be made is to the theorisation of Complexity within Composition - Appreciation. The issue with Complexity is that the probe question 'Was it hard to follow?' and examples of lexical instantiations seem more oriented to 'textual organisation' (p.57) rather than to 'things we make', 'performances we give' and 'natural phenomenon' (Martin and White, 2005, 56). The data analysis confirmed that the meaning of Complexity can actually extend beyond just textual organisation and is

Table 7 Instances of more delicate sub-categories of quality

\begin{tabular}{ll}
\hline Sub-categories & Instances of quality \\
\hline Aesthetics & I mean if the house is tidy (...) in that house and a little bit quiet is more preferable, \\
I think so. \\
Bản thân em thích chỗ nào đấy sạch sẽ, gọn gàng. \\
I myself like a place (which is) very clean and very tidy. \\
And the reason for moving I think is quite clear because the first place for me is just \\
temporary so that I can find a suitable place. \\
Đi tìm rất nhiều những chỗ phù hộp với mình mà lại không thuê đươc. \\
(I) went to look for many suitable places but I couldn't rent them. \\
And another reason is because the outline of the subject is also very clever, also \\
very scientific. \\
và mình thấy ngay cái hiệu quả luôn của việc nếu anh phát âm đúng. \\
...and I could see immediately the effectiveness of correct pronunciation. \\
Because it's very near my university. It's very convenient for me to commute. \\
Mọi thiết bị trong nhà đều tiện lợi. \\
All the facilities in the house are convenient.
\end{tabular}




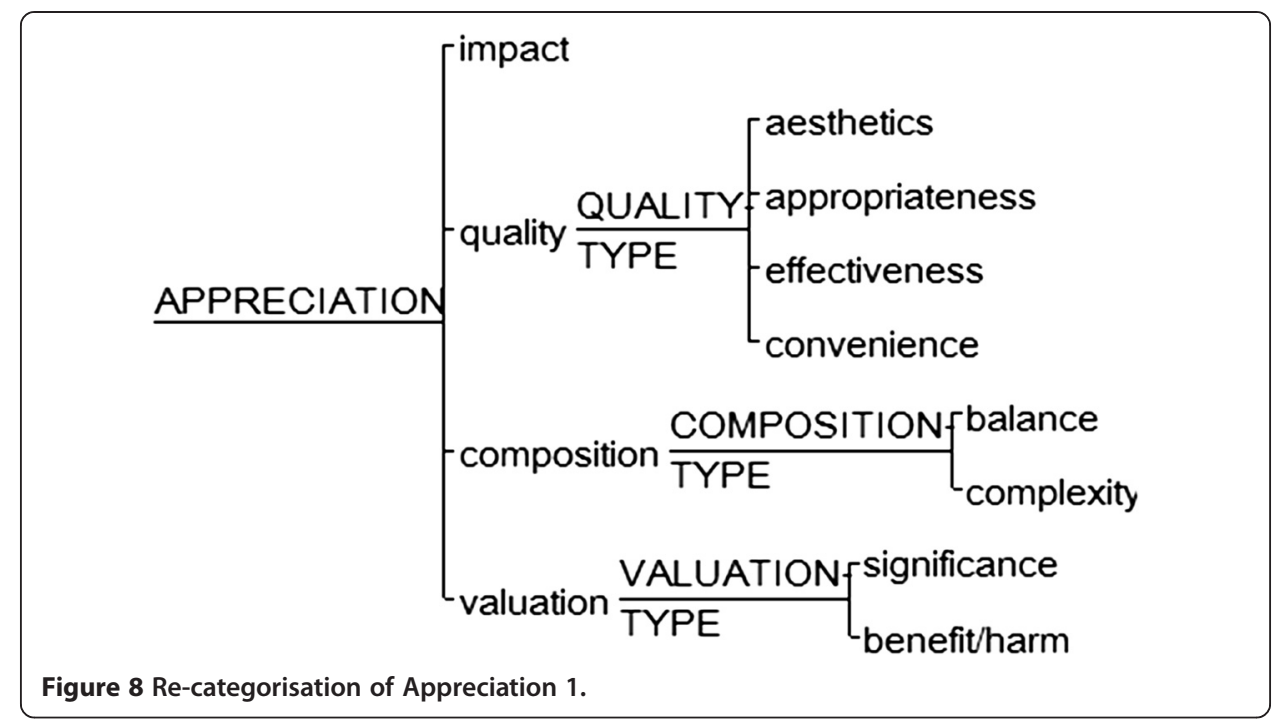

suggestive of the need to 'stretch' the current concept of Complexity beyond its strong orientation to 'textual organisation'. Instances of Complexity oriented to 'textual organisation' as proposed by Martin and White (2005) were still found in both the English as Vietnamese data as shown in Table 8.

Other instances suggest that Complexity can also refer to the complex nature of entities, phenomena or human activities in addition to the current 'textual organisation' orientation of this category. Such instances from both the English and Vietnamese data are exemplified in Table 9.

What is in common in the evaluative meaning of the instances in Table 9 is the sense of manageability towards the target of evaluation. Manageability can also be considered a quality or a standard referring to the relative ease of dealing with matters. With the extension of the concept of Complexity as discussed above, evaluation of the manageability of entities and activities no longer fits in the same category as the evaluation of 'textual organisation'. This entails the need to lift this concept out of Composition to establish a separate additional category under Quality, termed 'Manageability'. The meaning of textual Complexity remains under Composition with its parallel option 'Balance'. The newly proposed Appreciation category in Figure 8 can now be extended as in Figure 9.

Table 8 Instances of 'textual' complexity

\begin{tabular}{ll}
\hline Polarity & Instances of 'textual' complexity \\
\hline Positive & I always receive a very clear explanation from him. \\
& So the teacher who is a good teacher will give the children the basic knowledge. \\
& Nó có 1 cái quy định rất rõ ràng là người nào, tuần nào dọn. \\
& It has a very clear rule that who does the cleaning and when. \\
& Dạy cho sinh viên cách viết từng thể loại thì sẽ chi tiết hơn. \\
& Teaching students to write in each genre is more detailed. \\
& He always makes the lectures too hard to follow. \\
Negative & Hiểu được sự khác nhau của từng thể loại văn bản báo chí là rất phức tạp. \\
& Understanding the differences in different text types in journalism is really complicated.
\end{tabular}


Table 9 Instances other than textual complexity

\begin{tabular}{|c|c|}
\hline Polarity & Instances other than 'textual' complexity \\
\hline \multirow[t]{2}{*}{ Positive } & ...ở những khu gần trường, cho thuê lại phòng thì dễ hơn. \\
\hline & ...in places near the uni, sub-leasing rooms is easier. \\
\hline \multirow[t]{4}{*}{ Negative } & $\begin{array}{l}\text { Basically I'm a music teacher. So it's different field compare with other. It's interesting too, but } \\
\text { it's (a) challenge. }\end{array}$ \\
\hline & Life is hard without a car. \\
\hline & Còn khi vợ sang rồi thì tốt nhất trong nhà chỉ có nam thôi vì cứ có phụ nữ vào thì phức tạp. \\
\hline & $\begin{array}{l}\text { But after the wives arrive, it is best that in the house there are only men because it is complicated } \\
\text { whenever there are women. }\end{array}$ \\
\hline
\end{tabular}

\section{Conclusion}

This paper has presented a two-stage process of modification and refinement of the original Attitude framework (Martin and White, 2005). The re-theorizing and the refinements to the framework were stimulated by the pilot data analysis, complemented by a rigorous critical literature review, then confirmed and extended by the analysis of a large amount of data in the main study. The methodology exemplifies a model for refining and re-theorising a linguistic framework to be robustly applied in linguistic analysis of a particular field in a particular context, starting with the collection and analysis of a small sample using extant theory, then development of the refined model based on a larger study. In the current study, the first stage of refinements involved the recategorisation of Dis/Inclination and In/Security in the Affect system and the retheorisation of Impact and Quality in the Appreciation system. The re-categorisation of Dis/Inclination ad In/Security enabled a consistent data coding in the main study. The retheorisation of Impact and Quality was important as it helps distinguish the two concepts as one relating to an interactive emotive response to things (Impact) while the other is referring to a designated standard (Quality). The validity of this re-theorisation was confirmed by the main study data analysis.

The second stage of refinements involved an extension of Judgement and Appreciation. Judgement was extended in terms of types of Normality (to include subtypes of

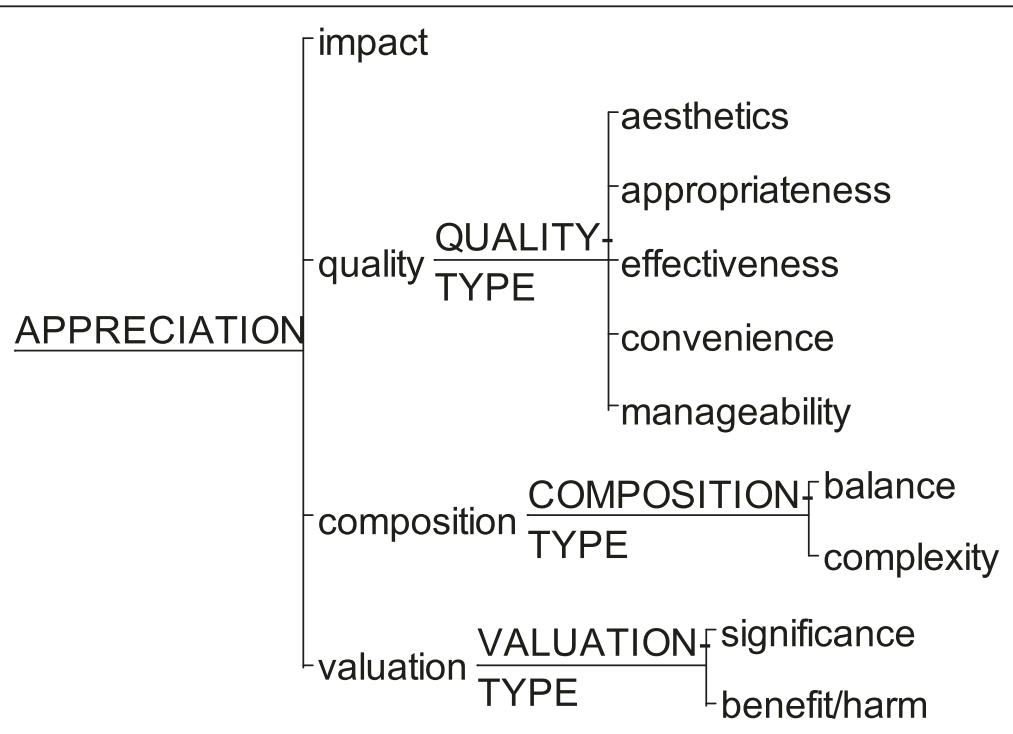

Figure 9 Re-categorisation of Appreciation 2. 
Fortune, Reputation and Behaviour) and Capacity (to include subtypes of Mental, Material and Social Capacity). Appreciation was extended to include more delicate subsets of Quality with Aesthetics, Appropriateness, Effectiveness, Convenience and Manageability. The refinements of Appreciation were particularly context dependent, and in this study, the refinements derived from the context of semi-casual oral discussion of topics relating to everyday life, academic and professional matters. The context- specific nature of Appreciation found in this study is consistent with findings from other research such as Hommerberg and Don (2014) and Macken-Horarik and Isaac (2014). In the context of wine appreciation, Hommerberg and Don $(2014,9)$ extended the category of Composition to include, for instance, 'Intensity' and 'Persistence' in addition to the original subcategories of 'Balance' and 'Complexity'. In the context of narrative, Macken-Horarik and Issac $(2014,85)$ established an additional Composition subtype to include 'Prominence'.

The recommended refined Attitude system will enable a more delicate coding of attitudinal meaning in similar contexts, which pedagogically plays a very important role in TESOL education, particularly in relation to international students from non-English speaking backgrounds who prepare to pursue their study in an English speaking country. A more delicate system as proposed will better facilitate the work of language teachers by providing them with a toolkit to support learners to develop a repertoire of diverse attitudinal meanings and linguistic resources in realising these attitudinal meanings, thus, enabling language learners to achieve more evaluative precision in communication in contexts that they will certainly encounter as an international tertiary student in an English speaking country.

Consistent with a number of previous studies investigating the language of evaluation in distinctive contexts (e.g. Hood 2010, Hao and Humphrey 2012, Hommerberg and Don 2014, Macken-Horarik and Isaac 2014, etc.) the present study has contributed to the further evolution of the appraisal framework as formulated by Martin and White (2005). These progressive refinements have enhanced the analytic efficacy of the framework as it is increasingly widely used in research and at the same time have endorsed the robustness of the fundamental theoretical underpinning of the original conceptualisation by Martin and White (2005). Such refinements principally add delicacy to the framework and in some cases extend its comprehensiveness, so that robustness is increased and the most current version of the framework is better able to account for data in new areas of research.

Abbreviations

SFL: Systemic functional linguistics; ESL: English as a second language; IELTS: International English Language Testing System; +ve: Positive; -ve: Negative; Aff: Affect.

Competing interests

The authors declare that they have no competing interests.

Authors' contributions

This paper reports one section of TN's Ph.D thesis under the supervision of LU. LU provided advice with the theoretical framework, design and data analysis of this study. TN drafted the manuscript of this paper in close collaboration with LU in terms of scope, content and structure. LU provided iterative reviews and suggested revisions of the paper. Both authors read and approved the final manuscript. 
title 'The deployment of the language of evaluation in English and Vietnamese spoken discourse', in which she examined English and Vietnamese evaluative language repertoires of Vietnamese postgraduate students in Australia. Len Unsworth is Professor in English and Literacies Education at the Australian Catholic University in Sydney. His recent book publications include Reading Visual Narratives (Equinox, 2013) with Clare Painter and Jim Martin, and with Angela Thomas, English Teaching and New Literacies Pedagogy: Interpreting and authoring digital multimedia narratives (Peter Lang Publishing 2014).

\section{Acknowledgements}

In preparing this manuscript, we would like to express our sincere thanks to our colleagues, Associate Professor Mary Macken-Horarik and Doctor Sally Humphrey who provided their critical feedback for improving the paper. Our thanks also go to Prof. Geoff Thompson for his valuable feedback in the previous draft of this paper.

\section{Author details}

${ }^{1}$ School of Education, University of New England, Armidale 2351, NSW, Australia. ${ }^{2}$ Learning Sciences Institute, Australian Catholic University, Level 18, Tenison Woods House, 8-20 Napier Street, North Sydney 2059, NSW, Australia.

Received: 23 January 2015 Accepted: 16 March 2015

Published online: 28 March 2015

\section{References}

Adendorff, R, and V de Klerk. 2005. The role of appraisal resources in constructing a community response to AIDS. Linguistics and Human Sciences 1(3): 489-513.

Becker, Annette. 2009. Modality and engagement in British and German political interviews. Languages in Contrast 9(1): $5-22$.

Bednarek, M. 2008. Emotion Talk Across Corpora. London/New York: Palgrave Macmillan.

Brick, Jean. 2009. Academic Culture: A Student's Guide to Studying at University: Macmillan Education AU.

Brown, P, and SC Levinson. 1987. Politeness: Some universals in language usage. Vol. 4. Cambridge: Cambridge University Press.

Caldwell, D. 2009. "Working Your Words': appraisal in the AFL post-match interview. Australian Review of Applied Linguistics 32(2): 13.

Canale, M, and M Swain. 1980. Theoretical bases of com-municative approaches to second language teaching and testing.' Applied Linguistics 1(1):1-47.

Celce-Murcia, M. 2007. 'Rethinking the role of communicative competence in language teaching.' In Intercultural language use and language learning, 41-57. The Netherlands: Springer.

Celce-Murcia, M, Z Dörnyei, and S Thurrell. 1995. Communicative competence: A pedagogically motivated model with content specifications. Issues in Applied linguistics 6(2): 5-35.

Christie, Frances, and James Robert Martin. 2005. Genre and institutions: Social processes in the workplace and school. Great Britain: Continuum.

de Silva Joyce, H, and S Feez. 2012. Text-based Language and Literacy Education - Programming and Methodology. Sydney: Phoenix Education.

Economou, D. 2006. 'The Big Picture: the Role of the Lead Image in Print Feature Stories.' Mediating Ideology in Text and Image. Ten Critical Studies, 211-233. Amsterdam/Philadelphia: John Benjamins.

Economou, D. 2009. Photos in the News: Appraisal Analysis of Visual Semiosis and Verbal-Visual Intersemiosis.

Economou, D. 2012. 'Standing out on Critical Issues: Evaluation in Large Verbal-visual Displays in Australian Broadsheets.' Multimodal Texts from Around the World: Cultural and Linguistic Insights, 246.

Eggins, S. 2000. 'Researching Everyday Talk.' In Researching Language in Schools and Communities: Functional Linguistic Perspectives, edited by Len Unsworth, 130. London and Washington: Cassell.

Eggins, S, and D Slade. 1997. Analysing Casual Conversation. London/Washington: Cassell.

Gass, S.M. 2006. Speech acts across cultures: Challenges to communication in a second language. Vol. 11. Germany: Walter de Gruyter.

Hao, J, and S Humphrey. 2012. The role of 'coupling'in biological experimental reports. Linguistics and the Human Sciences 5(2): 169-194.

Hommerberg, Charlotte, and Don Alexanne. 2014. 'Appraisal and the Language of Wine Appreciation: A Critical Discussion of the Potential of the Appraisal Framework as a Tool to Analyse Specialised Genres.' Functions of Language.

Hood, S. 2010. Appraising Research: Evaluation in Academic Writing. New York: Palgrave.

Hood, S, and G Forey. 2008. The interpersonal dynamics of call-centre interactions: co-constructing the rise and fall of emotion. Discourse \& Communication 2(4): 389.

Humphrey, S. 2008. Adolescent Literacies for Critical Social and Community Engagement. University of New England: Doctoral, School of Education.

Kopytko, R. 2000. Interactional pragmatics: towards a theory of performance. Studia anglica posnaniensia 35: 117-136.

Leech, G. 1983. Principles of Pragmatics. Vol. 1. London: Longman.

Lipovsky, C. 2008. Constructing affiliation and solidarity in job interviews. Discourse \& Communication 2(4): 411.

Lipovsky, C. 2013. 'Appraising One's Skills and Competences in a CV 'Appraisal Symposium 2013: Current Issues in Appraisal Analysis. Sydney: UNSW.

Macken-Horarik, M, K Love, and L Unsworth. 2011. A grammatics 'good enough'for school English in the 21st century: Four challenges in realising the potential. Australian Journal of Language and Literacy 34(1): 9-23.

Macken-Horarik, Mary. 2003. 'Appraisal and the special instructiveness of narrative.'. In Text: An Interdisciplinary Journal For The Study of Discourse: Negotiating Heterglossia: Social Perspectives on Evaluation, ed. Macken-Horarik Mary and Martin James Robert. Berlin: Walter de Gruyter.

Macken-Horarik, Mary, and Anne Isaac. 2014. Appraising Appraisal. In Evaluation in Context, 67. 
Martin, JR. 2000. Beyond Exchange: Appraisal System In English. In Evaluation in text: Authorial Stance and the Construction of Discourse, ed. S Hunston and G Thompson. Oxford: Oxford University Press.

Martin, JR, and D Rose. 2003. Working with discourse: Meaning beyond the clause. New York: Continuum International Publishing Group.

Martin, JR, and PRR White. 2005. The Language of Evaluation: Appraisal in English. London/New York: Palgrave/Macmillan. Miller, DR. 2007. 'Towards a Typology of Evaluation in Parliamentary debate: From theory to Practice-and back again.'. In (Re)volutions in Evaluation, ed. M Dossena and A Jucker, 159-180. Textus XX/1.

Redmond, MV. 2000. Cultural distance as a mediating factor between stress and intercultural communication competence. International Journal of Intercultural Relations 24(1): 151-159.

Savignon, SJ. 1983. Communicative Competence: Theory and Classroom Practice. Texts and Contexts in Second Language Learning. ERIC: The Addison-Wesley Second Language Professional Library Series.

Spencer-Oatey, H (ed.). 2000. Culturally speaking: Culture, Communication and Politeness Theory. New York: Continuum. Swain, E. 2012. 'Analysing Evaluation in Political Cartoons.' Discourse, Context \& Media.

Unsworth, L. 2013. Persuasive Narratives: Evaluative Images in Picture Books and Animated Movies.' Appraisal Symposium 2013: Current Issues in Appraisal Analysis. Sydney: UNSW.

Watts, RJ. 2003. Politeness. Cambridge: Cambridge University Press.

White, Peter RR. 2012. Attitudinal meanings, translational commensurability and linguistic relativity. Revista canaria de estudios ingleses 65: 147-159.

White, Peter RR. 1998. 'Telling Media Tales: The News Story as Rhetoric.' Doctoral, Dept. of Linguistics, Faculty of Arts, University of Sydney.

Yeh, CJ, and M Inose. 2003. International students' reported English fluency, social support satisfaction, and social connectedness as predictors of acculturative stress. Counselling Psychology Quarterly 16(1): 15-28.

\section{Submit your manuscript to a SpringerOpen ${ }^{\circ}$ journal and benefit from:}

- Convenient online submission

- Rigorous peer review

- Immediate publication on acceptance

- Open access: articles freely available online

- High visibility within the field

Retaining the copyright to your article 